\title{
Research into the History of Ghana
}

ConsIderable historical research has been undertaken in recent years by the Departments of History and Archaeology and the Institute of African Studies of the University of Ghana. Most of the archaeological work resulting from the emergency measures made necessary by the flooding of large areas by the Volta Hydro-Electric Project has not yet been published in final form, but a medium is now provided by the West African Archaeological Journal and the Monograph Series of the Department of Archaeology.

Excavations carried out since 1963 have made it possible to link the documented evidence of the European settlements with the undocumented contemporary indigenous cultures, and for Gonja a picture has been built up of some of the cultures comprised within the Gonja state since the sixteenth century. Detailed correlation between the important findings of Goody, Wilks, and Levtzion in the field of manuscript and oral tradition on the one hand and excavated evidence on the other is already possible in some cases. It is here that further excavation would show the most immediately profitable results for a combined research programme, but it is in the forest areas that this kind of research is most urgently needed, while detailed work at such sites as Begho and Bono-Manso would elucidate many of the problems of the trade from the Niger states.

The History Department at Legon is conducting research into French policy in West Africa, with particular reference to Senegal, and the connections between the Ga-AdangbeEwe-Mina and Fon groups in Togo and Dahomey. Islamic state formation in West Africa in the eighteenth and nineteenth centuries is being investigated by the Institute of African Studies. The Asante Research Project, launched by the Institute in 1963 with some financial support from UNESCO, is studying the society and culture of the area which historically fell within the Asante sphere of influence. The importance of the northern factor, first brought to attention in 196I, is recognized by the History Department's researches into the political and economic relationships between the Asante empire and its neighbours to the north. Considerable work has also recently been done at the Institute of African Studies on the assimilated areas to the north of Asante.

The Institute of African Studies has also been engaged in the collection of Arabic manuscripts as historical source materials. The works so far acquired have been predominantly of a religious nature, but priority is now to be given to historical material. The Institute's library contains some 475 Arabic manuscripts, catalogued and classified, and check lists are published in the Institute's Research Revien three times a year. Collection of stool histories and the Court records of traditional Asante is proceeding and should provide a comprehensive picture of the states in Ghana up to the beginning of the colonial period.

Plans for future research include the continuance of work on the Asante Research Project and the collection of Arabic manuscripts and court records, a pilot scheme on Mamprusi and, subject to availability of funds, the implementation of the Northern Research Scheme. It is also intended to direct more effort towatds the south-western states of Ghana on which hardly any work has yet been done.

\section{(Abridged from Institute of African Studies, University of Ghana, Research Review, vol. iv, no. 3, I968)}

\section{Researches in the Sudan}

THE second issue of The Sudan Research Information Bulletin, published by the Sudan Research Unit of the University of Khartoum, gives an account of current and completed researches and publications in various fields in anthropology and sociology. These include: political organization of the Humr Baggara-a cattle-owning tribe of south-western Khordofan 